\section{Development of a Simple Reference Evapotranspiration Model for Irrigation of Woody Ornamentals}

\author{
Richard C. Beeson, Jr., ${ }^{1,2}$ \\ Mid-Florida Research and Education Center, Institute of Food and Agricultural \\ Sciences, University of Florida, 2725 S. Binion Road, Apopka, FL 32703
}

Additional index words. irrigation, modeling, woody shrubs, nursery production, irrigation algorithm, crop coefficient, water need index

\begin{abstract}
Rooted cuttings of Rhaphiolepis indica, a low slow-growing evergreen shrub, were grown outdoors in weighing lysimeters to market size in 11.4-L containers. Actual evapotranspiration $\left(\mathbf{E T}_{\mathrm{A}}\right)$ and evaporation from containers shaded with plastic foliage was determined daily. The first 60 days after transplanting, substrate evaporation accounted for most of $\mathbf{E T}_{\mathrm{A}}$ and was the major component through the first 127 days. $\mathbf{E T}_{\mathrm{A}}$ generally followed variations in reference evapotranspiration (ETo). Mean cumulative ET $_{\mathrm{A}}$ to produce $90 \%$ of measured plants to market size was $101 \mathrm{~L}$ or $1.99-\mathrm{m}$ depth per plant based on container surface area. Water need indices, similar to crop coefficients, were highly correlated with percent canopy closure using an exponential decay equation $\left(r^{2}=0.898\right)$, but a more precise estimate at higher canopy closures was achieved using a third-order inverse polynomial equation $\left(r^{2}=0.907\right)$. When combined with similar previous data from Viburnum odoratissimum and Ligustrum japonicum, the inverse polynomial equation correlation was 0.802 for all three shrubs. This implies the \%Closure model provides a good general base for ETo-based irrigation of woody evergreen shrub species based on canopy size and spacing with improved precision when individual equations are derived by species.
\end{abstract}

Interest in reducing irrigation volumes during production of landscape ornamental plants has increased worldwide as population pressures on freshwater supplies have increased (Bacci et al., 2008; Caceres et al., 2008; Jury and Vaux, 2005). Early work by Burger et al. (1987) and Regan (1997) calculated crop coefficients $(\mathrm{Kc})$ to relate woody plant actual $\mathrm{ET}_{\mathrm{A}}$ to Penman-Montieth-based reference evapotranspiration. However, these Kcs were based on a fixed value of container surface area; thus, they are accurate only for plants of the same canopy and container size. Regan (1997) attempted to remedy this by periodically calculating Kcs per species and cultivar as they grew from liners to market size plants in 3.8-L containers. Later, Schuch and Burger (1997) used Fourier curve transformations to calculate $\mathrm{Kc}$, again based on upper container diameters for several species of woody ornamental plants to adjust for the quiescent period during the winter for plants that required two growing seasons to reach marketable size. Each species required a unique equation.

In 2004, a new model to calculate a crop coefficient, termed water needs index (WNI), was proposed (Beeson, 2004). The term was invented because nursery production and landscapes violate the conditions of a large

Received for publication 13 Oct. 2011. Accepted for publication 5 Jan. 2012.

${ }^{1}$ Associate Professor.

${ }^{2}$ To whom reprint requests should be addressed; e-mail rcbeeson@ufl.edu. uniform fetch required for calculating crop coefficients as defined previously (Doorenbos and Pruitt, 1977). WNI is calculated as a function of canopy closure of groups of plants, relating individual plant $\mathrm{ET}_{\mathrm{A}}$ to plant size and canopy ventilation and radiation (Beeson, 2005; Eq. 1):

$$
W N I=\frac{\left(E T_{A} \div P C A\right)}{E T o}
$$

where PCA is the horizontal planar projected canopy area and ETo is reference evapotranspiration. Under well-watered conditions, transpiration increases with canopy growth and is proportional to ETo. Concurrently, evaporation from the substrate surface remains constant or strate surface (Beeson, 2004, 2010b). As canopies expand to fill in the space between them, canopy closure approaches $100 \%$ and then increases greater than $100 \%$ as a result of branch overlap. As canopy closure increases beyond $67 \%$ to $100 \%$ closure, canopy ventilation is minimized with most $\mathrm{ET}_{\mathrm{A}}$ occurring in the upper $40 \%$ of the canopy at $100 \%$ closure (Beeson, 2010a), yet the reduced canopy transpiration is still strongly linked to ETo and horizontal planar-projected canopy size. Although the model was developed using Ligustrum japonicum Thunb. (ligustrum; Beeson, 2004), it was later shown to also be applicable to Viburnum odoratissimum Ker Gawl (viburnum; Beeson, 2010b). When data from the two species were combined, the correlation was 0.843 . Both species are considered upright spreading shrubs (DACS, 1994) and require the same production time of $\approx 12$ months to declines as canopies begin shading the sub- grow from rooted cuttings to market size (minimum $0.6 \mathrm{~m}$ tall by $0.45 \mathrm{~m}$ average width; DACS, 1994) in central Florida. Mean cumulative $\mathrm{ET}_{\mathrm{A}}$ was $8 \%$ greater for viburnum (155 L) than the ligustrum shrubs (143 L).

Rhaphiolepis indica (L.) Lindl. Ex Ker Gawl (Indian hawthorn) is a low-growing, mounding shrub (Halfacre and Shawcroft, 1989) and considered drought-tolerant. Growth is episodic with up to three flushes a year in central Florida. At marketable size in 11.4-L containers, canopies are $0.3 \mathrm{~m}$ tall and $0.45 \mathrm{~m}$ in average width, generally less than half $\left(0.061 \mathrm{~m}^{3}\right)$ the canopy volume of ligustrum or viburnum $\left(0.136 \mathrm{~m}^{3}\right)$. Objectives of this research were to quantify daily $\mathrm{ET}_{\mathrm{A}}$ of Indian hawthorn from transplanted rooted cutting to market size in 11.4-L containers. This along with environmental and growth data were used to evaluate applicability of the canopy closure model for plants with a low broad canopy architecture. The data here were also combined with previous data from ligustrum and viburnum to investigate the versatility of this model for contrasting species.

\section{Materials and Methods}

On 25 Apr. 2006, rooted cuttings of Rhaphiolepis indica (L.) Lindl (Indian hawthorn) produced in 5.7-cm peat pots (70000041; Jiffy Products of America, Lorain, $\mathrm{OH}$ ) were transplanted into 11.4-L black polyethylene containers (C1200; Nursery Supply, Chambersburg, PA) at the Mid-Florida Research and Education Center in Apopka, FL. Commercially prepared substrate (Florida Potting Soil, Inc., Apopka, FL) consisted of $55 \%$ pine bark fines:36\% Nupeat: $9 \%$ sand by volume and was amended with $2.9 \mathrm{~kg} \cdot \mathrm{m}^{-3}$ dolomite limestone and $0.86 \mathrm{~kg} \cdot \mathrm{m}^{-3}$ micronutrients (Micro-Max; Scotts Company Inc., Marysville, $\mathrm{OH}$ ). NuPeat is a mixture of equal parts of composted hardwood bark, composted yard waste, and Florida sedge peat that passes through a $12.5-\mathrm{mm}$ screen.

Containers were placed on black polyethylene ground cloth on 0.444 -m centers in a square arrangement within a production area measuring $9.2 \mathrm{~m} \times 9.8 \mathrm{~m}$. Containers were not respaced. The experimental area was irrigated at midnight as needed with overhead impact sprinklers situated at each corner. Before container placement, sprinkler heads were adjusted to achieve a Christiansen uniformity coefficient of 0.88 (Haman et al., 1977). Application rate for the irrigated area calculated after the final adjustment was 2.56 $\mathrm{cm} \cdot \mathrm{h}^{-1}$.

Fertilization. Each container was topdressed with $55 \mathrm{~g}$ of controlled-release fertilizer (18N-2.6P-9.9K; 18-6-12 Nutricote, 8 to 9 months; Florikan E.S.A, Sarasota, FL) on 25 Apr. 2006 and treated with pre-emergence herbicide (Ornamental Herbicide II; Scotts Co., Marysville, OH). On 28 Apr. 2006, and again 2 weeks later, each container was given $\approx 150 \mathrm{~mL}$ of a $300 \mathrm{mg} \cdot \mathrm{L}^{-1}$ nitrogen liquid fertilizer (Peter's 20-20-20; Scotts Co.) solution by hand. On 23 Feb. 2007, each container 
received $34 \mathrm{~g}$ of $14 \mathrm{~N}-6 \mathrm{P}-11.6 \mathrm{~K}$ Osmocote (14-14-14; Scotts Co.).

Data collection. Nine plants were selected and placed in suspension lysimeters for half hour recording of individual container-plant mass. Lysimeters consisted of $22.7-\mathrm{kg}$ load cells (SSM-AJ-50; Interface Inc., Scottsdale, AZ) suspended from 2.2-m tripods from which a basket was hung that suspended a container $\approx 2.5 \mathrm{~cm}$ above the ground surface (Beeson, 2011). Tops of lysimeter containers were less than $4 \mathrm{~cm}$ above surrounding containers. Lysimeters were placed in the middle of three banks of plants to prevent edge effects in a completely randomized design. Each bank was five rows wide and 19 plants long. Three additional lysimeters suspending substratefilled containers without plants were included within the production area to measure evaporation. Plastic foliage was added to these as needed to mimic canopy shading of substrate surfaces that occurred in containers of measured plants and did not interfere with substrate rehydration. Daily $\mathrm{ET}_{\mathrm{A}}$ for live plants and evaporation for controls were calculated by the data logger (CR10X; Campbell Scientific Inc., Logan, UT) based on changes in container-plant mass between 0600 HR and 2200 HR. On days with rain, manual calculations separated $\mathrm{ET}_{\mathrm{A}}$ from rain-induced changes in mass for each lysimeter (Beeson, 2006).

Daily reference ETo was calculated using Campbell Scientific's Application Note 4. Temperature and relative humidity were recorded using a CS-215 sensor (Campbell Scientific Inc.). Wind was measured with an anemometer (014A; Met One, Grants Pass, OR) at $2 \mathrm{~m}$ aboveground level. Solar radiation was measured with a pyranometer (LI-200X; LI-COR Inc., Lincoln, NE). ETo was calculated from data collected within $50 \mathrm{~m}$ of the experimental site.

Irrigation. For the first 3 weeks after transplanting, all plants were irrigated with $6 \mathrm{~mm}$ of overhead irrigation nightly to establish the plants. Thereafter, irrigation treatments were controlled by the lysimeter system. Irrigation of the production area was based on maximum $\mathrm{ET}_{\mathrm{A}}$ of lysimeter plants multiplied by a canopy shedding/irrigation uniformity factor set at 1.0 initially. This was increased in late winter to 1.2 to account for canopy shedding of overhead irrigation once canopies extended beyond container diameter (Beeson and Yeager, 2003). After the first 3 weeks, irrigation depths less than $0.63 \mathrm{~cm}$ were deferred to the next day and added to that day's irrigation application.

Calculations and modeling. Canopy measurements of widest width and width perpendicular to widest width were recorded on each lysimeter container and four adjacent border plants generally every 3 weeks beginning shortly after transplanting. The two widths were multiplied to calculate projected canopy area (PCA) for each plant. On 19 Apr. 2007, greater than $90 \%$ of measured plants had achieved market size (No. 1, $45 \mathrm{~cm}$ average width) based on Florida Grades and Standards (DACS, 1994).

Percent canopy closure (\%CC) was calculated for each lysimeter plant for each measurement date by adding the mean of half the PCA of each border plant to half the PCA of the respective lysimeter plant and then dividing by allocated bed area per plant $\left(1972 \mathrm{~cm}^{2}\right)$. Allocated bed area was the square of the distance on-center between plants. With growth, canopies filled the space between containers. Because containers were not respaced, canopies could overlap each other as shoots of each plant expanded outward and up. Because $\%$ CC was calculated on a fixed allocated bed area, this overlap resulted in calculation of $\% \mathrm{CC}$ greater than $100 \%$.

For modeling, $\mathrm{ET}_{\mathrm{A}}$ data for a $7-\mathrm{d}$ period centered on each growth measurement date was used. Daily $\mathrm{ET}_{\mathrm{A}}\left(\mathrm{cm}^{3}\right)$ of each lysimeter plant was converted to a depth by dividing by its PCA $\left(\mathrm{cm}^{2}\right) . \mathrm{ET}_{\mathrm{A}}$ depth $(\mathrm{cm})$ was then divided by the corresponding ETo $(\mathrm{cm})$ and averaged over the $7 \mathrm{~d}$ to estimate WNI (Eq. 1 and Beeson and Brooks, 2008) for each lysimeter plant at each measurement date. WNI values of the nine lysimeter replicates for each date were plotted against their respective $\% \mathrm{CC}$. The plot was fitted to a three-parameter exponential decay curve as reported by Beeson (2004) using SigmaPlot (Version 10; SPSS Science, Chicago, IL). The plot was also fitted to a third-order inverse polynomial equation also using SigmaPlot. Data previously reported for viburnum and ligustrum were combined with data reported here and the plot fitted to both the exponential decay curve and three-order inverse polynomial equation using SigmaPlot.

Data analysis. Daily $\mathrm{ET}_{\mathrm{A}}$ and evaporation were analyzed as repeated measures using GLM in SAS (Version 9.2; SAS Institute, Cary, $\mathrm{NC})$ with container water loss $\left(\mathrm{ET}_{\mathrm{A}}\right.$ and evaporation) as the main plot and time as the subplot (Snedecor and Cochran, 1980). T-tests $(P<$ $0.05)$ were used to compare between variables for each day.

\section{Results and Discussion}

In previously research with ligustrum (Beeson, 2004) and viburnum (Beeson, 2010b), evaporation from substrate surfaces for the first $60 \mathrm{~d}$ after transplanting (DAT) accounted for most of daily water loss. For hawthorn with their slower and more strongly episodic growth, there were no differences $(P>0.05)$ between $\mathrm{ET}_{\mathrm{A}}$ and evaporation for the first $127 \mathrm{DAT}$ (Day 225, Fig. 1). By 132 DAT, $\mathrm{ET}_{\mathrm{A}}$ from containers with live plants consistently exceeded evaporation of containers shaded by plastic plants. Lower values from approximately Day 145 to Day 228 corresponds to the summer rainy season, associated normally with increasing midday cloud cover and frequent rain, which suppressed ETo (Fig. 2) compared with May (Days 120 to 151). Mean daily water loss ranged from 51 to $380 \mathrm{~mL}$ from transplanting in late April 2006 until mid-February in 2007 (Day 45). Thus, for most of the production period, $\mathrm{ET}_{\mathrm{A}}$ of Indian hawthorn was $\approx 38 \%$ less than that of viburnum (Beeson, 2010b). Substantial increases in $\mathrm{ET}_{\mathrm{A}}$ began in early Mar. 2007 (approximately Day 65). Mean $\mathrm{ET}_{\mathrm{A}}$ of hawthorn doubled with spring growth, frequently achieving $700 \mathrm{~mL}$ per day during the last $30 \mathrm{~d}$ of production. Similar doubling of $\mathrm{ET}_{\mathrm{A}}$ with spring growth was reported for ligustrum (Beeson, 2004) and viburnum (Beeson, 2010b).

Container evaporation. Evaporation from containers was $\approx 275 \mathrm{~mL}$ immediately after transplanting until the rainy season began approximately Day 160 (early June; Fig. 1). From mid-August (Day 225) until mid-November (Day 318 ), evaporation was $\approx 200 \mathrm{~mL}$ per day because canopies generally shaded most of the substrate surface. Other than during the summer months, evaporation was similar to that measured previously for both ligustrum and viburnum through the end of winter (mid-March, Day 70). However, unlike either ligustrum or viburnum, evaporation from containers with plastic foliage tended to increase with increasing ETo (Fig. 2) in spring. This is likely because of the relatively shallow depth of hawthorn canopies and mimicked plastic foliage would

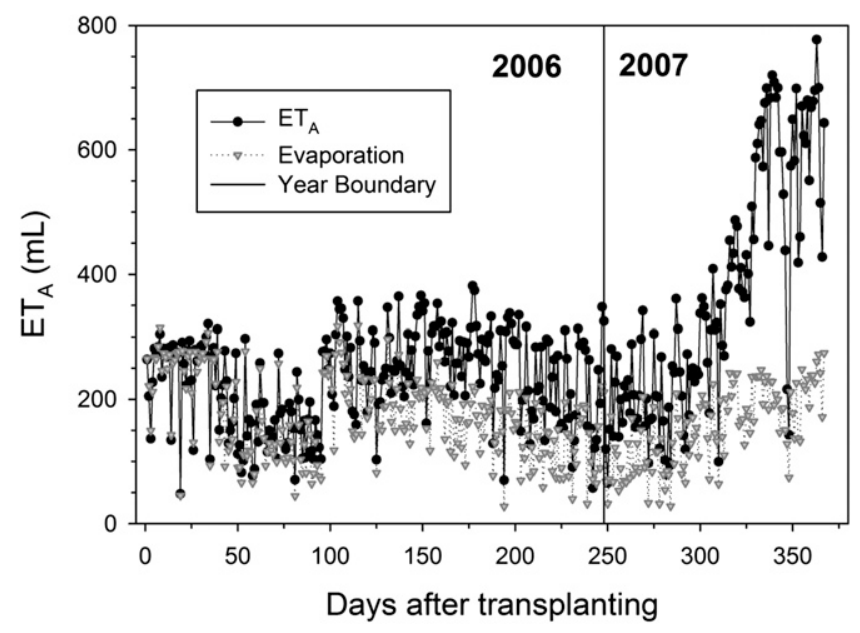

Fig. 1. Mean daily water loss through actual evapotranspiration $\left(\mathrm{ET}_{\mathrm{A}}\right)$ by Rhaphiolepis indica and evaporation from containers with artificial foliage from transplanting in late April 2006 until mid-Apr. 2007. The $\mathrm{ET}_{\mathrm{A}}$ line is representative of nine plant replicates, whereas the evaporation line is representative of three replicates. 
have resulted in less decoupling of substrate evaporation from air movement above canopies.

Hawthorn transpiration dipped in Dec. 2006 as a result of shorter days, lower ETo (Fig. 2), and termination of shoot growth in midNovember. ET $_{\mathrm{A}}$ increased in mid-February (Fig. 1) with increasing ETo (Fig. 2) and growth signified by PCA (Fig. 3). Canopy size increased beginning in early Feb. 2007, but major shoot flush did not occur until late March. With this shoot flush, plants achieved market size by late April, $\approx 1$ year after transplanting.

When summed over the production period, average $\mathrm{ET}_{\mathrm{A}}$ of hawthorn was $101.4 \pm 8.7 \mathrm{~L}$ or $1.99 \pm 0.17 \mathrm{~m}$ in depth based on top substrate surface area. $\mathrm{ET}_{\mathrm{A}}$ ranged from 91.2 to $117.0 \mathrm{~L}$ per plant. Mean $\mathrm{ET}_{\mathrm{A}}$ of hawthorn was $65 \%$ of that measured for viburnum (Beeson, 2010b) and $71 \%$ of that measured for ligustrum (Beeson, 2004). Rainfall during production was $0.8 \mathrm{~m}$, approximately one-third less than average annual rainfall. Although much of rainfall supplemented overhead irrigation, rainfall in excess of container capacity was of no value. Capacity to retain rainfall would have varied day to day but generally increased as plants grew larger and transpired greater daily volumes of water. Nightly irrigation based on highest $\mathrm{ET}_{\mathrm{A}}$ ensured that transpiration was fully coupled to ETo for all plants. At harvest, canopy widths averaged $0.47 \mathrm{~m}$ and average height was $0.24 \mathrm{~m}$. Average height was a bit shorter than the $0.3 \mathrm{~m}$ height specified in the Florida Grades and Standards but wider than the Standards for their height (DACS, 1994).

Modeling. The plot of WNI as a function of $\% \mathrm{CC}$ was fitted to an exponential decaying curve with an $r^{2}=0.898$ and $P=0.001$ (Fig. 4). This curve was based on individual plants because PCA was not uniform among replications; thus, means could not be calculated. Modeling based on individual plant WNI rather than a population WNI contributes to some of the variability. As shown previously with ligustrum and viburnum, WNI declined rapidly with small increases in plant size with the decline slowing $\approx 20 \%$ canopy closure at experimental spacing. For Indian hawthorn, this slowing of the decline in WNI would have been when an average plant canopy covered $\approx 90 \%$ of the container substrate top surface, occurring at approximately calendar Day 260.

Rapid declines in WNI at low canopy coverage occurred with increases in canopy growth for all three species. Transpiration was strongly coupled to the environment characterized by ETo, whereas substrate evaporation was not or was only weakly coupled as evidenced by generally consistent surface evaporation rates (Fig. 1). For young plants of all species, PCA was quite small, $6 \%$ to $12 \%$ of top substrate surface area (data not shown); thus, contribution of transpiration to $\mathrm{ET}_{\mathrm{A}}$ was also quite small. With $\mathrm{ET}_{\mathrm{A}}$ driven by evaporation, not plant transpiration, but divided by a plant's small PCA compared with the much larger substrate surface area, calculated WNI was high. With plant growth, both PCA and transpiration increased accounting for a larger

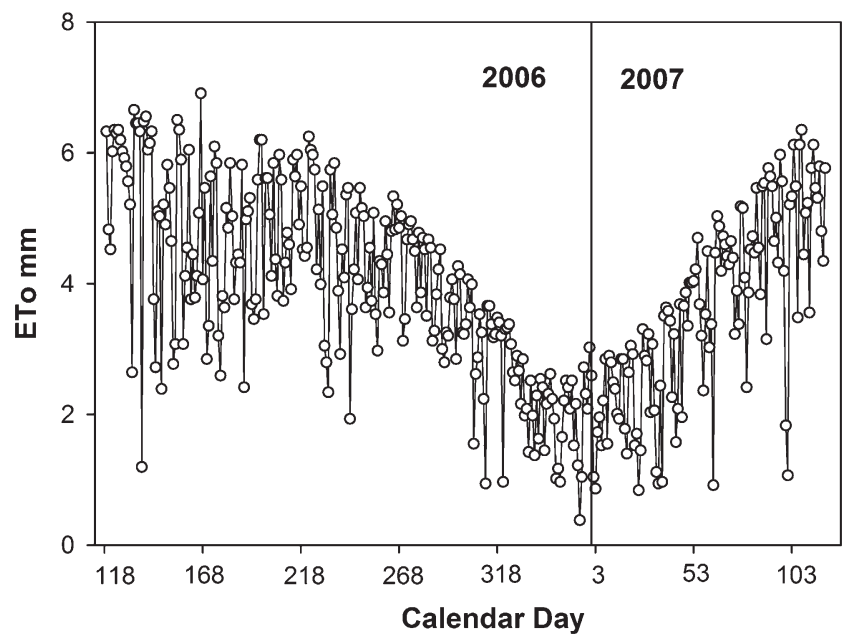

Fig. 2. Daily reference evapotranspiration (ETo) from Apr. 2006 through Apr. 2007 at MREC during the production of Rhaphiolepis indica.

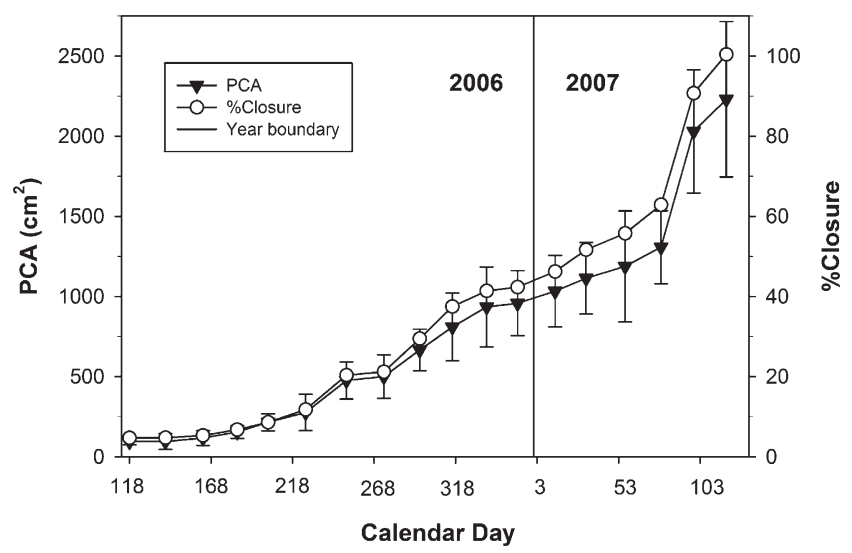

Fig. 3. Mean projected canopy area measured for Rhaphiolepis indica and calculated percent canopy closure, calculated from canopy widths and spacing between plants, during production from rooted cuttings to market size plants for 12 months beginning in late Apr. 2006. Each mean is representative of nine single plant replicates. Error bars are the SD of nine plant replicates for planar projected canopy (PCA).

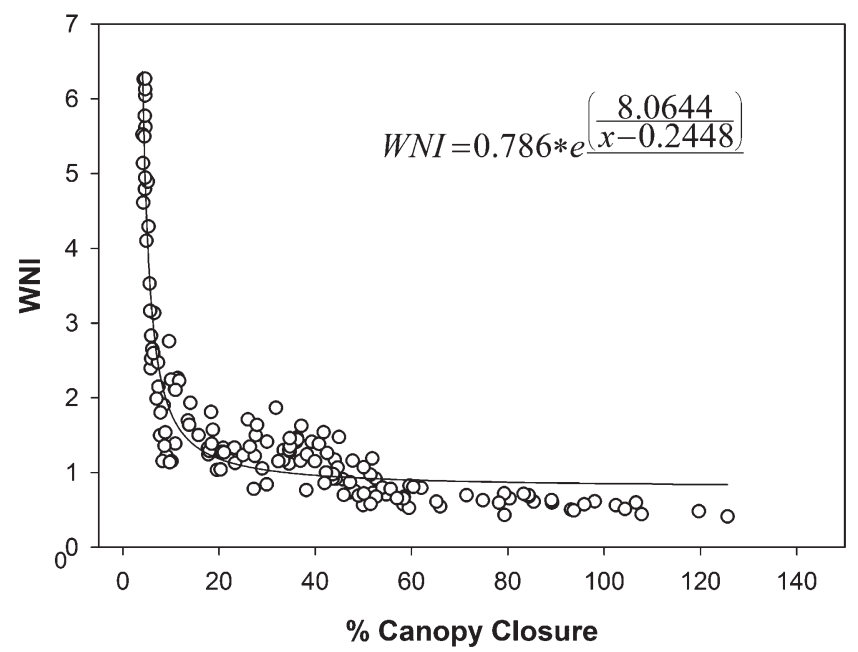

Fig. 4. Relationship between water needs index (WNI) values and corresponding percentage of canopy closure for Rhaphiolepis indica during production from rooted cuttings to market size plants in 11.4-L containers. Each point represents the individual value for a single plant averaged over a 7-d period centered on plant canopy measurements. The equation defines the decaying exponential curve that characterizes the relationship. 
portion of $\mathrm{ET}_{\mathrm{A}}$; thus, $\mathrm{ET}_{\mathrm{A}}$ became more responsive to ETo resulting in lower WNI.

For all species, rate of decline in WNI slowed $\approx 70 \%$ as $\%$ CC increased (Fig. 4). This level of canopy closure is within the range at which $\mathrm{ET}_{\mathrm{A}}$ declines as a function of mutual sheltering among plants (Beeson, 2010a). Unlike more vigorous growing ligustrum and viburnum, \%CC achieved by Indian hawthorn rarely achieved $100 \%$ before achieving market size and harvest. Most data for this model development occurred between $20 \%$ and $60 \%$ canopy closure, resulting in increased variability in this region (Fig. 4) with no plant canopy overlap. Overall bed area boundary layer resistance to water vapor transfer would have been low with entire canopies well coupled to the environment. This is in contrast to results from previous production beds of ligustrum and viburnum in which levels of \%CC achieved $230 \%$ to $350 \%$. Increased resistance to vapor transfer lowers $\mathrm{ET}_{\mathrm{A}}$ of individual plants, seen here as declines in WNI as \%CC increases. For forest trees, Rose (1984) predicted this response based on shading of lower leaves and strong reductions in horizontal air movement through the lower canopy. A mirror image of this effect occurs immediately after forests are thinned as boundary layer conductance of water vapor (Teklehaimanot et al., 1991) and transpiration (Bréda et al., 1995) increase as a result of greater coupling of a tree's entire canopy to the atmosphere rather than just the upper portion.

Values of WNI for all species were severalfold higher for young plants and proceeded in the opposite direction of $\mathrm{Kc}$ calculated for agronomic crops (Allen et al., 1998) and other woody species in containers (Burger et al., 1987; Niu et al., 2006; Regan, 1997; Schuch and Burger, 1997). When calculating Kc, evapotranspiration is divided by a fix surface area. Small plants with small transpiration rates have low initial Kc. As plants grow, increased transpiration is normalized by the same fix area, resulting in increasing Kc. Discussion of these differences and advantages of the \%CC model were discussed previously (Beeson, 2010b) and are not reiterated here.

Model equations. An issue with the threevalue decay exponential equation is that it loses precision after \%CC levels where individual canopies become decoupled, thereby overestimating WNI (Fig. 4). This was observed also with the other two species (data not shown). A search for a more precise equation resulted in selection of a third-order inverse polynomial equation. When used with Hawthorn data, this equation (Eq. 2) resulted in similar $r^{2}$ values (0.907) to the decay exponential equation but more accurately tracked hawthorn WNI at higher \%CC levels (Fig. 5).

$$
\begin{aligned}
W N I= & 0.444+\frac{26.527}{\% C C}-\frac{207.63}{\% C C^{2}} \\
& +\frac{837.5}{\% C C^{3}}
\end{aligned}
$$

where $\% \mathrm{CC}=(\mathrm{PCA} \div$ allocated bed area $) \times 100$ with superscripts indicating power functions.

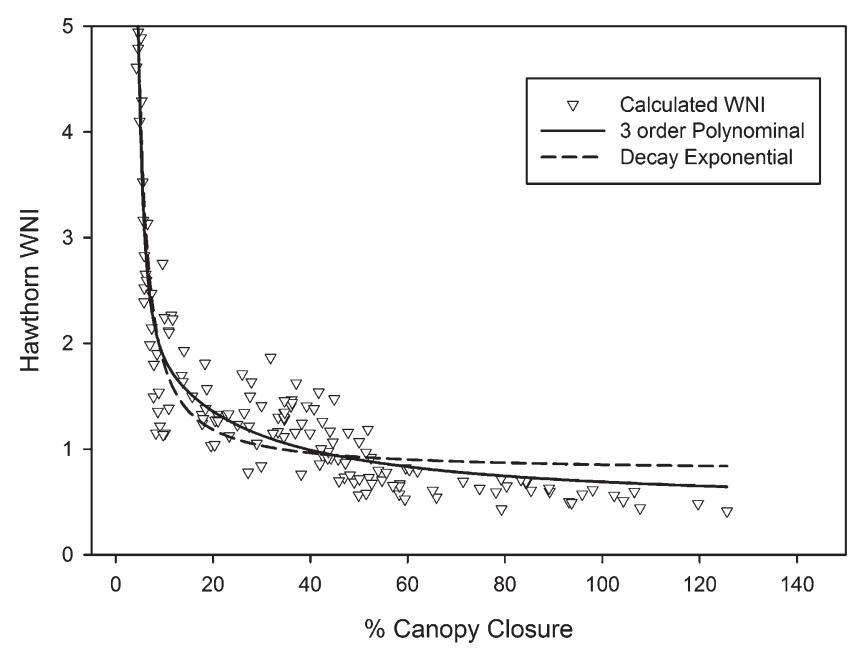

Fig. 5. Plot of water need indices (WNI) vs. percent canopy closure $(\% \mathrm{CC})$ for Raphalipis indica during production from rooted cuttings to market size plants. Each point represents the individual value for a single plant averaged over a 7-d period centered on plant canopy measurements. Lines indicate plots of the two different equations used to model the data.

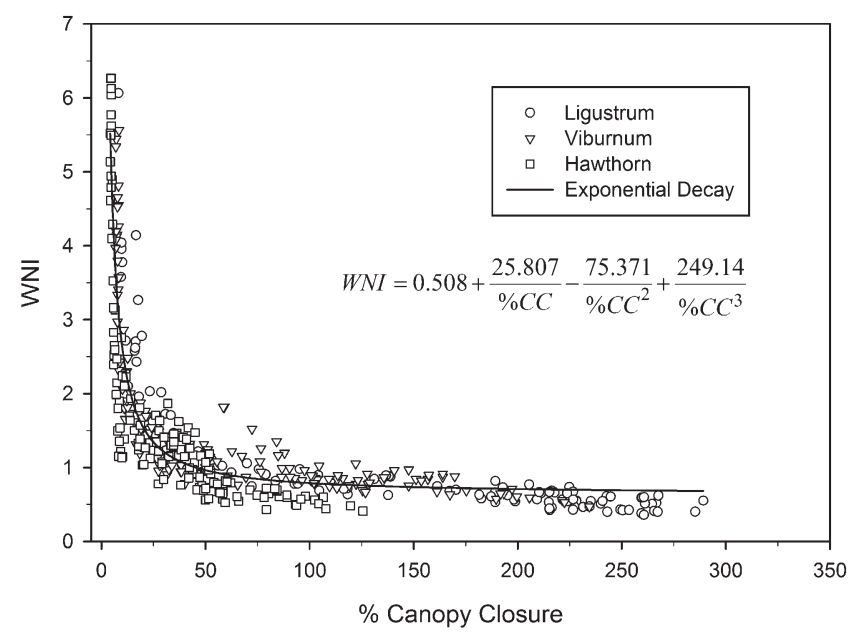

Fig. 6. Plot of pooled calculated water need indices (WNI) against their corresponding percent canopy closures for Ligustrum japonicum, Viburnum odoratissimum, and Raphiolepis indica. Each point represents the individual value for a single plant averaged over a 7-d period centered on plant canopy measurements. The line represents the best fit third-order inverse polynomial.

In the algorithm that uses the WNI, ETo, and PCA to calculate daily irrigation rates, canopy size increases the irrigation rate more rapidly than the resulting declines in WNI caused by increases in \% CC (Beeson, 2010b).

Data derived previously from ligustrum (Beeson, 2004) and viburnum (Beeson, 2010b) was pooled with that of hawthorn (Fig. 6). The resulting equation (Eq. 3) has an $r^{2}=0.802$.

$$
\begin{aligned}
W N I= & 0.508+\frac{25.807}{\% C C}-\frac{75.371}{\% C C^{2}} \\
& +\frac{249.14}{\% C C^{3}}
\end{aligned}
$$

This is less precise than that of individual curves using the inverse polynomial for ligustrum $\left(r^{2}=0.920\right)$, viburnum $\left(r^{2}=0.868\right)$, or Hawthorn $\left(r^{2}=0.907\right)$ but provides a good estimate of irrigation depths. The \% $\mathrm{CC}$ model is suggested as a simplistic vehicle for linking automated irrigation of container-grown woody species to local nursery microclimates.

\section{Conclusions}

The \%CC model offers a way to relate ETo to plant size and spacing for calculation of tailored irrigation rates from simple measurements. It was applicable across periods of quiescent growth and unaffected by season for evergreen species when minimum temperatures were greater than $0{ }^{\circ} \mathrm{C}$. Extreme temperatures during data collection for all three species ranged from less than -3 to greater than $36^{\circ} \mathrm{C}$. It should be applicable for deciduous species during the growing season because stomata response to environmental conditions are similar to evergreen species. Once the relationship between \%CC and WNI is established for a species, estimation of daily $\mathrm{ET}_{\mathrm{A}}$ could likely be applied across 
container sizes, although this has yet to be tested. The greatest short-term variability in a crop's water use in humid climates is directly related to the variability in solar radiation, which varies not only daily, but regionally. In arid climates, stomata closure resulting from high vapor pressure deficits (VPDs) could likely reduce daily $\mathrm{ET}_{\mathrm{A}}$ below that estimated by equations presented here for species that are sensitive to high VPD (Kjelgren et al., 2004), yet the basic model could still be valid if reductions in transpiration resulting from high VPD could be accounted for. Models based on physiological principles are the best avenue to make limited lysimeter data available to the nursery industry.

\section{Literature Cited}

Allen, R.G., L.S. Pereira, D. Raes, and M. Smith. 1998. Crop evapotranspiration: Guidelines for computing crop water requirements. FAO Irrigation and Drainage Paper 56, Rome, Italy.

Bacci, L., P. Bassista, and B. Rapi. 2008. An integrated method for irrigation scheduling of potted plants. Sci. Hort. 116:89-97.

Beeson, R.C., Jr. 2004. Modeling actual evapotranspiration of Ligustrum japonicum from rooted cuttings to commercially marketable plants in 12-liter black polyethylene containers. Acta Hort. 664:71-77.

Beeson, R.C., Jr. 2005. Modeling irrigation requirements for landscape ornamentals. HortTechnology 15:18-22.

Beeson, R.C., Jr. 2006. Relationship of plant growth and actual evapotranspiration to irrigation frequency based on managed allowable deficits for container nursery stock. J. Amer. Soc. Hort. Sci. 131:140-148.
Beeson, R.C., Jr. 2010a. Response of evapotranspiration of Viburnum odoratissimum to canopy closure and the implications for water conservation during production and in landscapes. HortScience 45:359-364.

Beeson, R.C., Jr. 2010b. Modeling actual evapotranspiration of Viburnum odoratissimum during production from rooted cuttings to market size plants in $11.4 \mathrm{~L}$ containers. HortScience 45:1260-1264.

Beeson, R.C., Jr. 2011. Suspension lysimeter systems for quantifying water use and modulating water stress for crops grown in organic substrates. Agr. Water Mgt. 98:967-976.

Beeson, R.C., Jr. and J. Brooks. 2008. Evaluation of a model based on ETo for precision irrigation using overhead sprinklers during nursery production of Ligustrum japonica grown in 11L containers. Acta Hort. 792:85-90.

Beeson, R.C., Jr. and T.H. Yeager. 2003. Plant canopy affects sprinkler application efficiency of container-grown ornamentals. HortScience 38:1373-1377.

Bréda, N., A. Granier, and G. Aussenac. 1995. Effects of thinning on soil and tree water relations, transpiration and growth in an oak forest [Quercus petraea (Matt.) Liebl.]. Tree Physiol. 15:295306.

Burger, D.W., J.S. Hartin, D.R. Hodel, T.A. Lukaszewski, S.A. Tjosvoid, and S.A. Wagner. 1987. Water use in California's ornamental nurseries. Calif. Agr. 41:7-8.

Caceres, R., J. Casadesus, and O. Marfa. 2008. Comparison of methods to automatically activate irrigation systems for shrubs species grown outdoors in containers. Acta Hort. 779:461470.

DACS (Florida Dept. of Agriculture and Consumer Services). 1994. Grades and standards for nursery plants. Fla. Dept. of Agr. and Consumer Services, Tallahassee, FL.
Doorenbos, J. and W.O. Pruitt. 1977. Guidelines for predicting crop water requirements. Irrigation and Drainage Paper 24. 2nd Ed. Food and Agriculture Organization of the United Nations, Rome, Italy.

Halfacre, R.G. and A.R. Shawcroft. 1989. Landscape plants of the southeast. Sparks Press, Inc., Raleigh, NC.

Haman, D.Z., A.G. Smajstrla, and D.J. Pitts. 1977. Uniformity of sprinkler and microirrigation systems for nurseries. Fla. Coop. Ext. Serv. Instit. Food and Agric. Sci. Univ. Fla. Bulletin 321.

Jury, W.A. and H. Vaux, Jr. 2005. The role of science in solving the world's emerging water problems. Proc. Natl. Acad. Sci. USA 102:15715-15720.

Kjelgren, R., R.C. Beeson, Jr., and T. Montague. 2004. Water use and stomatal behavior of sweetgum (Liquidambar styraciflua) relative to reference evapotranspiration in three contrasting regions. Acta Hort. 664:353-360.

Niu, G., D.S. Rodriguez, R. Cabrera, C. McKenney, and W. Mackay. 2006. Determining water use and crop coefficients of five woody landscape plants. J. Environ. Hort. 24:160-165.

Regan, R. 1997. Grouping container-grown plants by water use. The Digger. 41:24-27.

Rose, C.W. 1984. Modeling evaporation: An approach to heterogeneous communities. Agr. Water Mgt. 8:203-211.

Schuch, U.K. and D.G. Burger. 1997. Water use and crop coefficients of woody ornamentals in containers. J. Amer. Soc. HortScience 122:727734.

Snedecor, G.W. and W.G. Cochran. 1980. Statistical Methods. 7th Ed. Iowa State University Press. Ames, IA. pp. 507.

Teklehaimanot, Z., P.G. Jarvis, and D.C. Ledger. 1991. Rainfall interception and boundary layer conductance in relation to tree spacing. J. Hydrol. (Amst.) 123:261-278. 